

\title{
Determination of mineral matter and elemental composition of individual macerals in coals from Highveld mines
}

\author{
by R.H. Matjie*, Z. Lit ${ }^{\dagger \neq}$, C.R. Ward ${ }^{\dagger}$, J.R. Bunt*, and \\ C.A. Strydom**
}

\section{Synopsis}

A number of conventional and advanced analytical techniques (proximate and ultimate analysis, low-temperature oxygen-plasma ashing, X-ray diffraction, X-ray fluorescence spectrometry, coal petrography, and lightelement electron microprobe analysis) have been integrated and crosschecked to provide detailed characterization of coals from the Highveld coalfield in South Africa, as a basis for better understanding of the mineralogical and chemical properties of the individual coal sources that are blended as feedstocks for combustion and carbon conversion processes. The techniques included methods to quantify the abundance and composition of the mineral matter (minerals and non-mineral inorganic elements), and also the abundance and chemical composition of the individual macerals in the individual coals concerned.

Kaolinite is the most abundant of the minerals in the coals studied, with lesser but still significant proportions of quartz, mica and/or illite, dolomite, calcite, and pyrite. Small but variable proportions of anatase, goyazite, and siderite are present in some coal samples. Electron microprobe analysis, based on a special configuration for light-element study, shows that the vitrinite contains less carbon and more oxygen, and has significantly higher concentrations of nitrogen and organic sulphur, than the inertinite macerals in the same samples. Minor proportions of organically-associated inorganic elements, including titanium, were also identified in some of the maceral components.

A comprehensive knowledge of the minerals and non-mineral inorganic elements in the coals used for feedstock preparation, obtained by integration of data from these advanced analytical techniques with more conventional analyses, may be of benefit in understanding the processes that take place during coal utilization, and also in avoiding or ameliorating some of the operational and environmental problems that may occur in different sectors of the coal utilization industry.

\section{Keywords}

coal analysis, coal petrology, mineral matter, X-ray diffraction, electron microprobe. particles are pulverized to $100 \%$ passing $75 \mu \mathrm{m}$ and combusted in boilers to produce energy or electricity for the domestic power and chemical industries (van Alphen, 2005).

\section{Mineral matter in coal}

As discussed further by authors such as Benson (1987), Ward (2002), and van Alphen (2005), the material regarded as mineral matter in coal consists effectively of two fractions: (1) a range of discrete crystalline mineral particles occurring in the coal in different ways, and (2) a range of non-mineral inorganic elements dissolved in the pore water or intimately associated with the organic matter (Li et al., 2007, 2010; Mares et al., 2012). Along with other constituents such as organic sulphur, the mineral matter is the most significant factor in problems that may be associated with coal handling and use, such as abrasion, stickiness, slagging, sintering, corrosion, and pollution (Falcone et al., 1984; Tangsathitkulchai, 1986; Bryers, 1996; Gupta et. al., 1996; Wall et al., 2002; Creelman et al., 2013; Su et al., 2001; Barnes, 2009; Matjie et al., 2008, 2011, 2012a, 2012b). In addition, mineral matter occurring within the coal macerals, especially the non-mineral inorganic elements, is a key contributor to the formation of ultrafine ash particles, as well as condensed metallic vapours, during coal combustion (Buhre et al., 2006; Zhang, 2006).

\section{Introduction}

Low-grade, medium-rank $\mathrm{C}$ bituminous coals are mined for South African chemical companies from six different collieries in the Highveld coalfield, located in the Mpumalanga Province of South Africa (Pinheiro et al., 1998-1999). Products containing coarse coal particles mixed with rock fragments $(>6 \mathrm{~mm}$ coal fraction) are transported from the mine sources to the preparation plant, where they are blended according to their availability to form a mixture that is suitable for the company's coal conversion operations (Matjie et al., 2006; van Dyk et al., 2006). Finer coal
* Unit for Energy and Technololgy Systems, School of Chemical and Minerals Engineering, NorthWest University, Potchefstroom.

$\dagger$ School of Biological, Earth and Environmental Sciences, University of New South Wales, Sydney, Australia, and CSIRO Energy Flagship, North Ryde, Australia.

** School of Physical and Chemical Sciences, NorthWest University, Potchefstroom.

(c) The Southern African Institute of Mining and Metallurgy, 2016. ISSN 2225-6253. Paper received Jul. 2015; revised paper received Aug. 2015. 


\section{Determination of mineral matter and elemental composition of individual macerals}

The inorganic elements within the organic structure of coal macerals may react in a different way to the same elements occurring in the discrete mineral particles (Falcone et al., 1984; Ward, 2002). More specifically, Quann and Sarofim (1986) found that the organically-associated inorganic elements (calcium and magnesium) in lignitic coal react with free aluminium silicate to form fused agglomerates during combustion.

Many of the minerals in coal undergo chemical and crystallographic changes at the temperatures associated with combustion (O'Gorman and Walker, 1973; Vassilev et al., 1995; Creelman et al., 2013), including during preparation of laboratory ash samples for conventional (proximate) analysis procedures. The minerals in a coal sample are therefore usually isolated and identified by low-temperature oxygenplasma ashing (Gluskoter, 1965; Standards Australia, 2000), during which the coal is exposed, under vacuum, to a stream of electronically activated oxygen, which destroys the organic matter at a temperature of around $120^{\circ} \mathrm{C}$, leaving a residue consisting of the essentially unaltered mineral components. The organic sulphur in the coal macerals may, however, interact with organically-associated inorganic elements to form mineral artefacts in the plasma-ashing process (Frazer and Belcher, 1973). Non-mineral calcium, for example, may react with sulphur released from the coal to form bassanite $\left(\mathrm{CaSO}_{4} \cdot \frac{1}{2} \mathrm{H}_{2} \mathrm{O}\right)$ in the low-temperature ash residues of South African coal samples (Matjie et al., 2008, 2011, 2012a, 2012b; Hlatshwayo et al., 2009). The formation of such calcium sulphate artefacts provides an example of the greater reactivity shown by non-mineral inorganic elements during coal combustion, relative to equivalent or counterpart elements (e.g. calcium in calcite) occurring in less reactive mineral forms.

\section{Electron microprobe analysis of coal macerals}

Several authors (e.g. Raymond and Gooley, 1978; Raymond, 1982; Clark et al., 1984; Ward and Gurba, 1998) have used electron microprobe analysis and similar techniques to determine the concentration of organic sulphur in coal macerals. In practical terms this represents sulphur that cannot be removed from the coal, even if the pyrite and other sulphur-bearing phases are completely separated out by conventional preparation techniques (Ryan and Ledda, 1997).

As an extension of this approach, special light-element electron microprobe techniques have been used to determine the percentages of carbon, oxygen, and nitrogen in the individual macerals of coal samples (e.g. Bustin et al., 1993; Mastalerz and Gurba, 2001; Ward et al., 2005, 2007, 2008), providing a better understanding of the differences between the individual components of the organic matter to complement more conventional chemical and petrographic studies. This approach has also provided new insights into the occurrence of non-mineral inorganic elements, such as $\mathrm{Ca}, \mathrm{Mg}, \mathrm{Fe}$, and $\mathrm{Al}$, in the different coal macerals and the changes that may take place in those elements with advancing rank (Li et al., 2007, 2010).

\section{Significance of mineral matter in coal utilization}

The minerals and other inorganic elements in coal may interact with each other when the coal is used. The nature of these interactions and the impact of the associated products depend on the minerals involved, and also on factors such as the utilization conditions (e.g. temperature, oxidation/reduction), the mode(s) of mineral or element occurrence within the coal, and the opportunities for and duration of contact between the various phases in the utilization system (e.g. Bryers, 1996; Grigore et al., 2008; Matjie et al., 2011, 2012a, 2012b; Creelman et al., 2013).

In order to manage these processes and minimize their potentially adverse effects, it is important to have a good understanding of the chemical and mineralogical properties of the individual coals that contribute to the feedstock preparation, especially the nature and mode of occurrence of the different mineral matter components. Although a significant amount of information is available from chemical analyses (e.g. proximate analysis, ultimate analysis, ash analysis), and mineralogical analysis has also been carried out on some South African coals (Pinheiro et al., 1998-1999; Gaigher, 1980; DME, 2006; Pinetown et al., 2007; Matjie et al., 2011), very little information is available on the chemical composition of the actual macerals in South African coals or on the mineralogical composition of low-temperature ash residues isolated from South African coal samples.

The objective of this paper is to describe the application of two advanced analytical techniques - evaluation of mineral matter by quantitative X-ray diffraction and chemical analysis of coal macerals using the electron microprobe - to some industrially significant South African coals. As well as describing the techniques and the results obtained, the study includes comparisons with data from other, more conventional procedures, partly to check and confirm the results obtained and partly to illustrate the relation between the information from the advanced techniques and conventional coal analysis data. The use of such information in understanding the behaviour of South African coals during utilization is also included in the discussion.

\section{Experimental}

Samples of coal from six different mines in the Highveld coalfield were analysed. Each coal represents a component of the blend used for gasification and/or combustion applications in the Sasol industrial complex. Representative portions of each sample were crushed to the appropriate particle size and submitted to laboratories in South Africa and Australia for the analysis programme described below.

\section{Chemical analysis}

Representative portions of each coal were ground to 100\% passing $212 \mu \mathrm{m}$, and the ground samples were analysed by proximate analysis, using standard methods to measure the percentages of moisture (SABS 924, ISO 589), ash (ISO 1171), and volatile matter (ISO 562). Ultimate analysis of the coals was carried out using the ASTM D5373 procedure. The ASTM D4239 method was used to determine the total sulphur content. The overall results were expressed to a dry ash-free (daf) basis, and the oxygen content was calculated by difference.

Other portions of each coal were ground to fine powder and ashed at $815^{\circ} \mathrm{C}$ at the University of New South Wales in Sydney, Australia. The ashes were fused with lithium metaborate and cast into glass discs, following the method of 


\section{Determination of mineral matter and elemental composition of individual macerals}

Norrish and Hutton (1969). The discs were analysed by Xray fluorescence (XRF) spectrometry using a Philips PW 2400 spectrometer and SuperQ software, and the results were expressed as percentages of the major element oxides in each ash sample.

\section{Petrographic analysis}

Representative splits of each crushed coal were mixed with epoxy resin and prepared as polished sections for petrographic analysis. Petrographic analysis was carried out by Coal and Organic Petrology Services Pty Ltd, Sydney, Australia, based on optical microscopy using oil-immersion objectives. The procedure followed Australian Standard AS2856, based on ICCP guidelines and ISO 7404. The volumetric proportions of individual macerals and maceral groups, and also of the visible mineral components, were determined for each of the coals, as well as the mean maximum reflectance of the vitrinite in the coal samples.

\section{Low-temperature ashing and mineralogical analysis}

Other representative splits of each coal sample were finely powdered, and a representative portion of each powder subjected to low-temperature oxygen-plasma ashing using an IPC four-chamber asher at the University of New South Wales, as outlined in Australian Standard 1038, Part 22. The mass percentage of low-temperature ash (LTA) was determined in each case.

The mineralogy of each LTA from the coal was analysed by X-ray powder diffraction (XRD) using a Phillips X'pert diffractometer with $\mathrm{Cu} \mathrm{K} \alpha$ radiation, and the minerals present identified by reference to the International Center for Diffraction Data (ICDD) Powder Diffraction File. Quantitative analyses of mineral phases in each LTA were made using Siroquant ${ }^{\mathrm{TM}}$, a commercial XRD interpretation software package originally developed by Taylor (1991) based on the refinement principles described by Rietveld (1969).

The clay fraction (less than $2 \mu \mathrm{m}$ effective diameter) of each LTA sample was isolated by ultrasonic dispersion in sodium hexametaphosphate (Calgon) and subsequent settling. This fraction was concentrated, mounted on glass slides, and investigated in more detail by XRD of the resulting oriented aggregates using glycol and heat treatment (Hardy and Tucker, 1988). The relative proportions of the different clay minerals in this fraction for each sample were determined using the method described by Griffin (1971).

\section{Elemental composition of individual macerals}

Polished sections of representative coal fragments (approximately $5 \mathrm{~mm}$ diameter) were prepared from each sample. The fragments were selected to embrace the range of macerals in each sample, as indicated by the macroscopic appearance (lithotype) of the coal in each case.

The surfaces of the polished sections were coated with a thin film of carbon, and loaded into a Cameca SX-50 electron microprobe analyser at the University of New South Wales, equipped with the Windows ${ }^{\circledR}$-based SAMx operating system and interface software. The elemental chemistry of the individual macerals in each sample was analysed on this instrument using special light-element techniques, following procedures described more fully by Bustin et al. (1993) and Ward et al. (2005).
Images were also captured of selected fields of view for each sample (Figure 1) using the optical observation system of the microprobe unit. Although the resolution was less than that obtained by reflected-light microscopy under oil immersion and some details were obscured by the carbon coating, the light optics of the microprobe were found to be adequate for recognition of the individual macerals, based mainly on shape and other textural features.

Individual points on representatives of the different maceral groups were analysed for each sample using the operating conditions described by Ward et al. (2005). The accelerating voltage for the electron beam was $10 \mathrm{kV}$ and the filament current $20 \mathrm{nA}$, with a magnification of $20000 \mathrm{x}$, giving an beam spot size on the sample of around 5 to $10 \mu \mathrm{m}$ in diameter. As discussed by Bustin et al. (1993), an independently analysed anthracite sample was used as the standard for carbon in the analysis process. A range of mineral standards was used for the other elements (Li et al., 2010).

The percentages of carbon, oxygen, nitrogen, sulphur, silicon, aluminium, calcium, magnesium, potassium, titanium, and iron were measured for each selected point, with a note on the type of maceral represented in each case. The results of the individual analyses were tabulated in spreadsheet format. Although care was taken to analyse only 'clean' macerals and avoid areas where visible minerals were also present, the area analysed for some points unavoidably included significant proportions of mineral components (e.g.
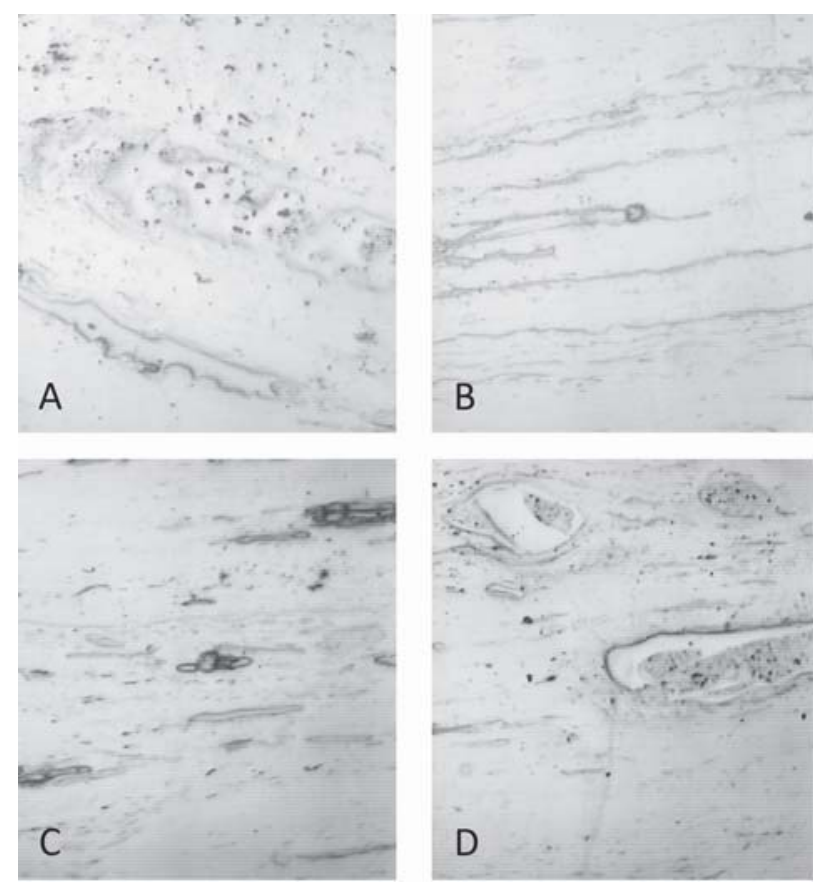

Figure 1-Images of polished sections as viewed under the electron microprobe. (A) Semifusinite (upper right) and minor vitrinite (lower left), sample 2; (B) cutinite (fine and elongated dark-grey stringers) distributed in vitrinite bands, sample 6; (C) sporinite (small dark-grey lenticles) surrounded mainly by vitrinite, sample 6; (D) fusinite particles (bright grains with high relief) surrounded mainly by vitrinite and semifusinite, sample 6. Height of each image is approximately $600 \mu \mathrm{m}$. Circular dots on images represent marks left by the electron beam after measurement 


\section{Determination of mineral matter and elemental composition of individual macerals}

quartz, clay, and pyrite) as well as the organic matter. Points that apparently included mineral contaminants (e.g. points with high $(>0.5 \%)$ Si or with particularly high percentages of both Fe and S) were excluded from consideration; so, too, were points that included some of the mounting epoxy resin (e.g. epoxy filling empty cell structures), indicated by unusual oxygen and high nitrogen contents.

\section{Results and discussion}

\section{Chemical analysis}

\section{Proximate and ultimate analysis}

Proximate analysis data (Table I) shows that the samples yield $30-34 \%$ volatile matter on a daf basis. The inherent moisture content of the coals ranges between $2.9 \%$ and $3.8 \%$, and the ash yield of the samples tested (air-dried basis) ranges between $22.1 \%$ and $29.7 \%$. Total sulphur content, determined as part of the ultimate analysis procedure (see below) ranges from $0.7 \%$ to $1.1 \%$ when expressed on an airdried basis.

Ultimate analysis data (Table II) indicates that the coals contain high proportions of carbon (77-80\% daf), with relatively low concentrations of total sulphur $(0.9-1.6 \%$ daf), nitrogen (2-2.1\% daf), and hydrogen (4.0-4.6\% daf). The oxygen content of the coals (daf basis) was found by calculation to range from 12 to $16 \%$.

\section{Coal ash analysis}

The proportions of inorganic elements (reported as oxides) in the coal ashes, derived from XRF analysis, are given in Table III. The percentage of ash for each sample analysed in this way, determined as part of the XRF analysis procedure, is also indicated. These percentages are slightly different from the ash percentages in Table I, partly because of differences in the samples actually analysed by the two laboratories, and also possibly because of differences in sulphur retention within the ashes due to different ash preparation techniques.

Silica $\left(\mathrm{SiO}_{2}, 47-58 \%\right)$ and alumina $\left(\mathrm{Al}_{2} \mathrm{O}_{3}, 21-28 \%\right)$ are the dominant constituents in the coal ashes, with lesser but still significant proportions of $\mathrm{CaO}, \mathrm{Fe}_{2} \mathrm{O}_{3}, \mathrm{MgO}$, and $\mathrm{TiO}_{2}$. Other oxides, with the exception of $\mathrm{SO}_{3}$ and in some cases $\mathrm{P}_{2} \mathrm{O}_{5}$ and $\mathrm{K}_{2} \mathrm{O}$, each make up less than $1 \%$ of the coal ash samples.

The percentage of sulphur retained as $\mathrm{SO}_{3}$ in the ash is less than that expected if all of the sulphur in the coal (the total sulphur in Table I) was retained in this way. As with the formation of bassanite in oxygen-plasma ash discussed above, the extent of sulphur retention depends partly on the ashing conditions (e.g. heating rate) and partly on the proportion of elements such as $\mathrm{Ca}$ that are available to combine with the $\mathrm{S}$ released from the coal during the ashing process. For example, the lowest percentage of $\mathrm{SO}_{3}$ in Table III occurs in sample 2, which also has the lowest percentage of $\mathrm{CaO}$, and the highest $\mathrm{SO}_{3}$ percentage occurs in sample 6, which has the highest $\mathrm{CaO}$ percentage. Links between $\mathrm{CaO}$ and $\mathrm{SO}_{3}$ in ashes prepared under similar conditions are discussed further by Koukouzas et al. (2009).

\section{Petrographic analysis}

Petrographic analysis (Table IV) indicates that the coals are inertinite-rich, with significant proportions $(9-27 \%)$ of visible mineral matter. If the minerals are excluded and the maceral percentages recalculated to $100 \%$, the coals contain $19-30 \%$ vitrinite and $64-77 \%$ inertinite components on a mineral-free basis. Liptinite makes up between 3 and $5 \%$ (mineral-free) of the coal samples. Samples 5 and 6 contain slightly higher proportions of vitrinite and liptinite and lower proportions of inertinite than the other coal samples.

The vitrinite in the coals is represented mainly by relatively thick bands of collotelinite (telocollinite). Finer bands of collodetrinite (desmocollinite) occur in minor proportions, typically as a structureless matrix containing other maceral components. The principal inertinite maceral is semifusinite, with minor proportions of inertodetrinite,

\section{Table I \\ Proximate analysis data (air-dried basis) for the coals tested}

\begin{tabular}{|l|r|r|r|r|r|r|}
\hline Sample number & $\mathbf{1}$ & $\mathbf{2}$ & $\mathbf{3}$ & $\mathbf{4}$ & $\mathbf{5}$ & $\mathbf{6}$ \\
\hline Moisture (\%) & 3.3 & 2.9 & 3.2 & 3.4 & 3.0 & 3.8 \\
Ash (\%) & 24.5 & 29.0 & 29.7 & 27.2 & 26.8 & 22.1 \\
Volatile matter (\%) & 21.7 & 22.9 & 21.3 & 21.5 & 22.4 & 23.1 \\
Fixed carbon (\%) & 50.5 & 45.2 & 45.8 & 47.9 & 47.8 & 51.0 \\
Total sulphur (\%) & 1.1 & 1.0 & 0.8 & 1.0 & 1.1 & 0.7 \\
Volatile matter (daf basis, \%) & 30.1 & 33.6 & 31.7 & 31.0 & 31.9 & 31.2 \\
\hline
\end{tabular}

Table II

Ultimate analysis data for the coals tested (dry, ash-free basis)

\begin{tabular}{|l|c|c|c|c|c|c|}
\hline Sample number & $\mathbf{1}$ & $\mathbf{2}$ & $\mathbf{3}$ & $\mathbf{4}$ & $\mathbf{5}$ & $\mathbf{6}$ \\
\hline Carbon (\%) & 79.9 & 78.5 & 77.1 & 77.8 & 79.0 & 77.9 \\
Hydrogen (\%) & 4.36 & 4.55 & 4.07 & 4.12 & 4.59 & 4.29 \\
Nitrogen (\%) & 2.12 & 2.00 & 1.97 & 2.00 & 2.08 & 2.00 \\
Total sulphur (\%) & 1.55 & 1.41 & 1.15 & 1.50 & 1.62 & 0.92 \\
Oxygen (\% by difference) & 12.1 & 13.5 & 15.7 & 14.6 & 12.7 & 14.9 \\
& & & & & & \\
\hline
\end{tabular}

Table III

Inorganic oxide percentages (wt\%) from XRF analysis of coal ash samples

\begin{tabular}{|c|c|c|c|c|c|c|}
\hline Sample number & 1 & 2 & 3 & 4 & 5 & 6 \\
\hline Ash $\left(815^{\circ} \mathrm{C}\right)$ & 28.9 & 40.6 & 30.8 & 32.8 & 30.6 & 22.8 \\
\hline $\mathrm{SiO}_{2}$ & 51.27 & 53.67 & 52.17 & 49.63 & 58.25 & 46.79 \\
\hline $\mathrm{Al}_{2} \mathrm{O}_{3}$ & 24.70 & 27.95 & 26.40 & 27.05 & 21.22 & 23.71 \\
\hline $\mathrm{Fe}_{2} \mathrm{O}_{3}$ & 4.31 & 3.69 & 2.46 & 3.55 & 3.48 & 3.74 \\
\hline $\mathrm{TiO}_{2}$ & 1.24 & 1.29 & 1.54 & 1.48 & 1.15 & 1.43 \\
\hline $\mathrm{P}_{2} \mathrm{O}_{5}$ & 0.40 & .070 & 0.67 & 0.83 & 0.70 & 1.17 \\
\hline $\mathrm{CaO}$ & 7.46 & 5.70 & 8.08 & 7.75 & 6.19 & 13.27 \\
\hline $\mathrm{MgO}$ & 2.19 & 1.67 & 2.64 & 2.11 & 1.70 & 3.64 \\
\hline $\mathrm{Na}_{2} \mathrm{O}$ & 0.41 & 0.22 & 0.50 & 0.36 & 0.38 & 0.55 \\
\hline $\mathrm{K}_{2} \mathrm{O}$ & 0.79 & 1.13 & 0.84 & 1.21 & 1.07 & 0.35 \\
\hline $\mathrm{SO}_{3}$ & 5.57 & 4.50 & 4.94 & 5.59 & 4.47 & 6.13 \\
\hline Total & 98.33 & 100.52 & 100.24 & 99.56 & 98.60 & 100.78 \\
\hline
\end{tabular}




\section{Determination of mineral matter and elemental composition of individual macerals}

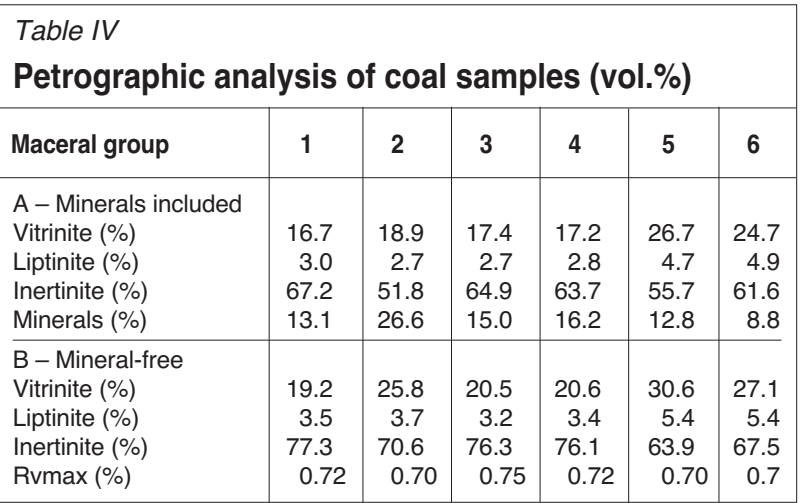

macrinite, and fusinite, and traces of micrinite are also present. Sporinite and cutinite are the only liptinite macerals present, with sporinite being especially abundant in the liptinite-rich coals represented by samples 5 and 6 .

The minerals or mineral-rich components visible under the microscope are mainly disseminated clays, with minor carbonate and traces of quartz and pyrite. Stony particles (shale) are also present in the crushed coal grain mounts, especially in the mineral-rich coal of sample 2 . It should be noted that the percentages in Table IV are all volume percentages; since minerals such as quartz and clays typically have densities around twice those of the macerals in coal, the weight percentages of mineral material would be significantly higher, as a fraction of the coal, than the volume percentages indicated in the table.

The coals have a mean maximum vitrinite reflectance, measured on collotelinite (telocollinite), of 0.70-0.75\%. According to ISO 11760 (ISO, 2005), this indicates that the coals can be classified as medium-rank $\mathrm{C}$ bituminous coals.

\section{Mineralogy of $L T A$ residues}

Table V summarizes the weight percentage of LTA isolated from the coals by oxygen-plasma ashing, and also the percentages of the individual minerals in each LTA, based on the powder XRD and Siroquant evaluations. Figure 2 illustrates typical X-ray diffractograms of the LTA from the coal samples.

Figure 3A provides a plot of the LTA percentage for each sample against the percentage of high-temperature $\left(815^{\circ} \mathrm{C}\right)$ ash indicated for the same coal sample in Table III. The plot includes a diagonal line, along which the data points would be expected to fall if both percentages were equal. The data points, however, fall above this equality line, indicating that the percentages of mineral matter, expressed by the LTA, are slightly higher than the high-temperature ash yields from the same coal samples. This is because the LTA contains an abundance of essentially unaltered minerals, such as clay minerals, pyrite, and carbonates, which liberate volatile components and leave a lesser proportion of altered mineral residue after the high-temperature ashing process. For example, although quartz is non-reactive, kaolinite loses around $14 \%$ by mass and calcite loses around $44 \%$ on hightemperature ashing, due to dehydroxylation and decarbonization reactions respectively. The slope factor (1.08) in the linear regression equation indicates that, on average, the overall proportion of mineral matter (LTA) in the coal samples is typically around $8 \%$ higher than the (hightemperature) ash yield.

\begin{tabular}{|c|c|c|c|c|c|c|}
\hline \multicolumn{7}{|c|}{$\begin{array}{l}\text { Table } V \\
\text { Mineralogy (wt\%) of LTA from coal samples from } \\
\text { powder XRD analysis }\end{array}$} \\
\hline Sample number & 1 & 2 & 3 & 4 & 5 & 6 \\
\hline LTA & 31.9 & 43.9 & 34.5 & 36.2 & 33.6 & 24.6 \\
\hline Quartz & 17.6 & 21.5 & 20.6 & 15.2 & 20.1 & 18.3 \\
\hline Kaolinite & 51.4 & 50.4 & 49.5 & 44.0 & 50.8 & 47.6 \\
\hline Illite & bld & 5.7 & bld & 5.7 & 5.3 & 2.2 \\
\hline Mica & 10.4 & 7.4 & 7.0 & 6.9 & 4.5 & 4.5 \\
\hline Calcite & 2.1 & 1.2 & 2.7 & 9.8 & 1.8 & 4.6 \\
\hline Dolomite & 10.3 & 6.4 & 11.7 & 10.0 & 10.2 & 15.2 \\
\hline Siderite & bld & 1.3 & 0.9 & 0.4 & 0.3 & 1.4 \\
\hline Pyrite & 2.4 & 1.4 & 1.6 & 1.4 & 2.6 & 2.0 \\
\hline Bassanite & 2.1 & 1.4 & 1.6 & 2.5 & 1.9 & 2.5 \\
\hline Goyazite & 1.0 & 1.7 & 2.7 & 3.0 & 1.4 & 0.9 \\
\hline Anatase & 2.7 & 1.5 & 1.6 & 1.0 & 1.0 & \\
\hline
\end{tabular}

Note: bld = below limit of detection

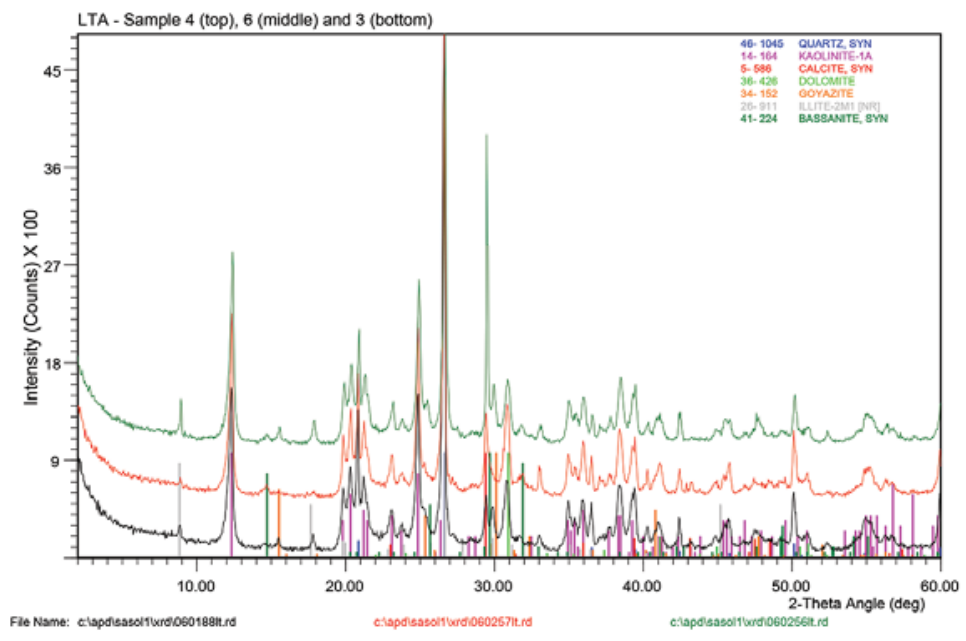

Figure 2-X-ray powder diffractograms of typical LTA residues, showing peaks used to identify individual major mineral components 


\section{Determination of mineral matter and elemental composition of individual macerals}
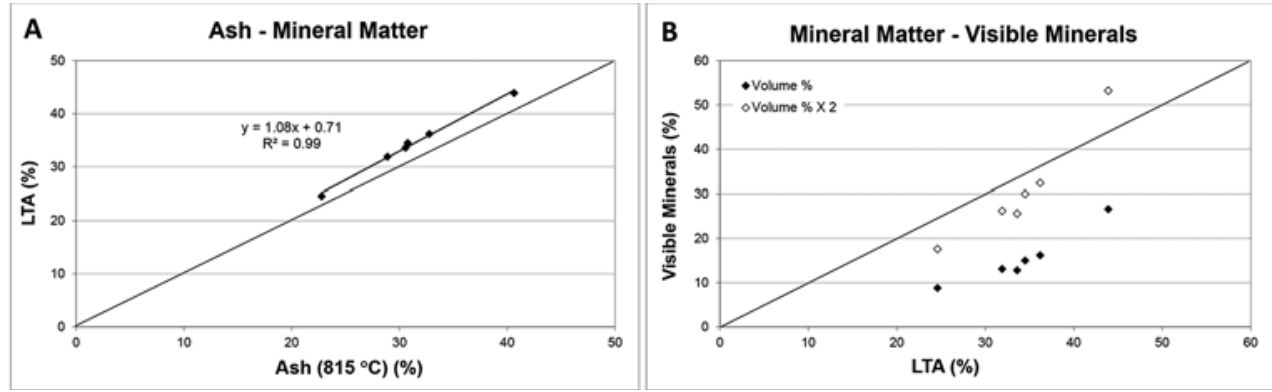

Figure 3-(A) Comparison of LTA percentage to ash yield for coals analysed in the study; (B) comparison of volumetric percentage of mineral components determined by petrographic analysis (solid symbols) to LTA percentage for samples studied. Open symbols represent an approximate comparison by weight, based on multiplying the volumetric percentages by two to allow for density differences between minerals and macerals

Figure 3B shows the relation between the percentage of mineral matter as indicated by the LTA and the percentage of visible mineral components identified during petrographic analysis. Because the petrographic data provides volume, not mass, percentages, and because the minerals have higher densities than the macerals, the volume percentages indicated by optical microscopy (solid symbols) are significantly lower than the weight percentages indicated by the plasma-ashing data. However, if the volume percentages of the minerals are multiplied by two (open symbols) to allow for the differences in density and thus to represent approximate weight percentages, the mineral percentages indicated by the petrographic analyses fall close to the equality line, suggesting a broad consistency in the data from the two different sources.

As indicated in Table V and Figure 2, the LTA derived from the six coals is made up mainly of kaolinite, with lesser proportions of quartz, mica and/or illite, and dolomite, and minor proportions of siderite, calcite, pyrite, anatase, and the aluminophosphate mineral goyazite $\left(\mathrm{SrAl}_{3}\left(\mathrm{PO}_{4}\right)_{2}(\mathrm{OH})_{5} \cdot \mathrm{H}_{2} \mathrm{O}\right)$. A small proportion of bassanite $\left(\mathrm{CaSO}_{4} \cdot \frac{1}{2} \mathrm{H}_{2} \mathrm{O}\right)$ is also present in the LTA samples; as discussed above, this was probably derived from interaction of organically-associated calcium in the coals with organic sulphur during the low-temperature ashing process (Frazer and Belcher, 1973; Matjie et al., 2008, 2011, 2012a, 2012b).

Further data on the clay minerals, based on the separate oriented aggregate XRD study of the $<2 \mu \mathrm{m}$ fraction, is provided in Table VI. The results differ in some ways from the bulk analysis data for the same minerals in Table V; different fractions were analysed in each case, and different methods were used for the mineral percentage estimations. Kaolinite is the dominant mineral in the clay fraction of all of the LTAs. Small proportions of illite are present in the clay fraction of most samples, along with a somewhat greater relative proportion of expandable-lattice clay material. In most of the LTAs the expandable clay is represented by irregularly interstratified illite/smectite (I/S), but in two of the samples (sample 1 and sample 3 ) a separate smectite phase is also present. Detailed identification of such phases is difficult from the XRD powder patterns alone (Figure 1), partly because of the relatively low overall proportions present in the LTAs and partly because the poorly-ordered crystal structures of those minerals produce diffuse peaks in the powder diffractograms.

\section{Comparison of mineralogical and chemical data}

The chemical composition of the (high-temperature) coal ash expected from each of the coals, based on the mineralogy of the LTA residues, was calculated from the mineral percentages listed in Table $\mathrm{V}$ and the chemical composition of the individual minerals based either on stoichiometry or on typical analyses of the same minerals published in the literature ( $\mathcal{f} f$. Ward et al., 1999). The results, presented in Table VII, allow for loss of hydroxyl groups from the clay minerals, $\mathrm{CO}_{2}$ from the carbonates, and changes in the pyrite at high temperature. They were also normalized to exclude $\mathrm{SO}_{3}$ associated with the bassanite in the LTA material.

\section{Table VI \\ Clay mineralogy (wt \%) of $<2 \mu \mathrm{m}$ fraction from oriented aggregate XRD analysis of coal LTA samples}

\begin{tabular}{|c|c|c|c|c|}
\hline $\begin{array}{l}\text { Sample } \\
\text { number }\end{array}$ & $\begin{array}{c}\text { Kaolinite } \\
\%\end{array}$ & $\begin{array}{c}\text { Illite } \\
\%\end{array}$ & $\begin{array}{l}\text { Expandable } \\
\text { clay } \%\end{array}$ & $\begin{array}{c}\text { Nature of } \\
\text { expandable clay }\end{array}$ \\
\hline 1 & 93 & 1 & 6 & Mainly smectite \\
\hline 2 & 92 & 3 & 5 & Mainly irregular I/S \\
\hline 3 & 90 & 2 & 8 & Smectite + regular I/S \\
\hline 4 & 92 & 3 & 5 & Regular to irregular I/S \\
\hline 5 & 93 & 3 & 4 & Mainly irregular I/S \\
\hline 6 & 96 & 0 & 4 & Mainly irregular I/S \\
\hline
\end{tabular}

Note: $\mathbf{I} S \mathbf{S}=$ interstratified (mixed-layer) illite-smectite

\begin{tabular}{|c|c|c|c|c|c|c|}
\hline \multicolumn{7}{|c|}{$\begin{array}{l}\text { Table VII } \\
\text { Inferred ash chemistry }\left(\mathrm{SO}_{3} \text {-free) based on }\right. \\
\text { Siroquant data }\end{array}$} \\
\hline Sample number & 1 & 2 & 3 & 4 & 5 & 6 \\
\hline $\mathrm{SiO}_{2}$ & 55.17 & 59.32 & 56.18 & 51.33 & 57.57 & 54.02 \\
\hline $\mathrm{Al}_{2} \mathrm{O}_{3}$ & 28.86 & 29.09 & 27.51 & 28.18 & 28.55 & 26.58 \\
\hline $\mathrm{Fe}_{2} \mathrm{O}_{3}$ & 1.91 & 2.02 & 1.95 & 1.46 & 2.28 & 2.73 \\
\hline $\mathrm{TiO}_{2}$ & 3.22 & 1.74 & 1.92 & 1.23 & 1.19 & 0.99 \\
\hline $\mathrm{P}_{2} \mathrm{O}_{5}$ & 0.41 & 0.67 & 1.10 & 1.26 & 0.57 & 0.38 \\
\hline $\mathrm{CaO}$ & 6.27 & 3.93 & 7.27 & 12.20 & 5.98 & 10.27 \\
\hline $\mathrm{MgO}$ & 2.69 & 1.63 & 3.08 & 2.70 & 2.66 & 4.13 \\
\hline $\mathrm{Na}_{2} \mathrm{O}$ & 0 & 0 & 0 & 0 & 0 & 0 \\
\hline $\mathrm{K}_{2} \mathrm{O}$ & 1.47 & 1.61 & 0.99 & 1.64 & 1.20 & 0.91 \\
\hline
\end{tabular}




\section{Determination of mineral matter and elemental composition of individual macerals}

Similar data for the high-temperature ash analyses by XRF spectrometry, normalized to exclude $\mathrm{SO}_{3}$, is given in Table VIII. Figure 4 provides graphic plots comparing the principal oxide percentages indicated by the two different techniques. Equal ranges for the axes are used in each case, and each plot includes a diagonal line along which the points would fall if the percentages indicated by each technique were equal.

Although individual outliers are represented on some of the plots, the bulk of the data points for $\mathrm{SiO}_{2}, \mathrm{Al}_{2} \mathrm{O}_{3}, \mathrm{CaO}$, and $\mathrm{MgO}$ fall close to the diagonal equality line. This suggests that the quantitative percentages in the mineralogical analyses (Table V) are generally consistent with the chemical data independently determined by XRF analysis of the respective high-temperature ash materials. One sample (sample 5) appears as an outlier on the plot for $\mathrm{Al}_{2} \mathrm{O}_{3}$, with a low percentage of $\mathrm{Al}_{2} \mathrm{O}_{3}$ indicated by the XRF data compared to that inferred from the XRD results. This may reflect inconsistencies between the actual coal samples subjected to analysis by the two different techniques, such as variations in the balance between the clay and non-clay components.

The plot for $\mathrm{K}_{2} \mathrm{O}$ appears to indicate a consistent overestimation from the XRD data compared to the actual percentage as indicated by direct ash analysis. However, as discussed more fully in other studies (e.g. Ward et al., 1999), this is probably due to incorporation of lower than expected proportions of $\mathrm{K}$ into the interlayer crystallographic spaces of the illite in the coals, which was not allowed for in the stoichiometric compositions used for illite in calculating the inferred chemical compositions from the XRD data. This is reinforced by the presence of I/S, and in some cases smectite, in the clay fraction of the LTA residues, which was not detected in the powder XRD patterns used for the inferred ash chemistry calculations.
The data for $\mathrm{Fe}_{2} \mathrm{O}_{3}$, on the other hand, suggests a consistent under-estimation of Fe-bearing phases by XRD analysis, with most points falling below the equality line. This may be due to errors in the determination of Fe-bearing phases due to absorption of the $\mathrm{Cu}$ radiation used for the XRD analysis ( $c f$. Ward et al., 2001), inclusion of Fe in the structure of the calcite and dolomite (which was not allowed for when calculating the inferred oxide percentages), or possibly the presence of Fe in noncrystalline form (e.g. poorly crystalline Fe oxyhydroxides) within the mineral matter.

\section{Elemental composition of individual coal macerals}

The results of the electron microprobe analyses of the coal macerals are summarized in Table IX. This data represents the average proportion of each element in each maceral for the respective samples, based on the number of individual points indicated in each case.

\begin{tabular}{|c|c|c|c|c|c|c|}
\hline Sample number & 1 & 2 & 3 & 4 & 5 & 6 \\
\hline $\mathrm{SiO}_{2}$ & 55.24 & 55.87 & 54.71 & 52.79 & 61.84 & 49.40 \\
\hline $\mathrm{Al}_{2} \mathrm{O}_{3}$ & 26.62 & 29.09 & 27.69 & 28.77 & 22.53 & 25.03 \\
\hline $\mathrm{Fe}_{2} \mathrm{O}_{3}$ & 4.65 & 3.84 & 2.58 & 3.78 & 3.69 & 3.95 \\
\hline $\mathrm{TiO} 2$ & 1.33 & 1.34 & 1.62 & 1.57 & 1.22 & 1.51 \\
\hline $\mathrm{P}_{2} \mathrm{O}_{5}$ & 0.43 & 0.72 & 0.70 & 0.88 & 0.74 & 1.24 \\
\hline $\mathrm{CaO}$ & 8.04 & 5.93 & 8.47 & 8.24 & 6.57 & 14.01 \\
\hline $\mathrm{MgO}$ & 2.36 & 1.74 & 2.77 & 2.24 & 1.80 & 3.84 \\
\hline $\mathrm{Na}_{2} \mathrm{O}$ & 0.44 & 0.23 & 0.52 & 0.38 & 0.41 & 0.58 \\
\hline $\mathrm{K}_{2} \mathrm{O}$ & 0.85 & 1.17 & 0.88 & 1.29 & 1.13 & 0.37 \\
\hline
\end{tabular}
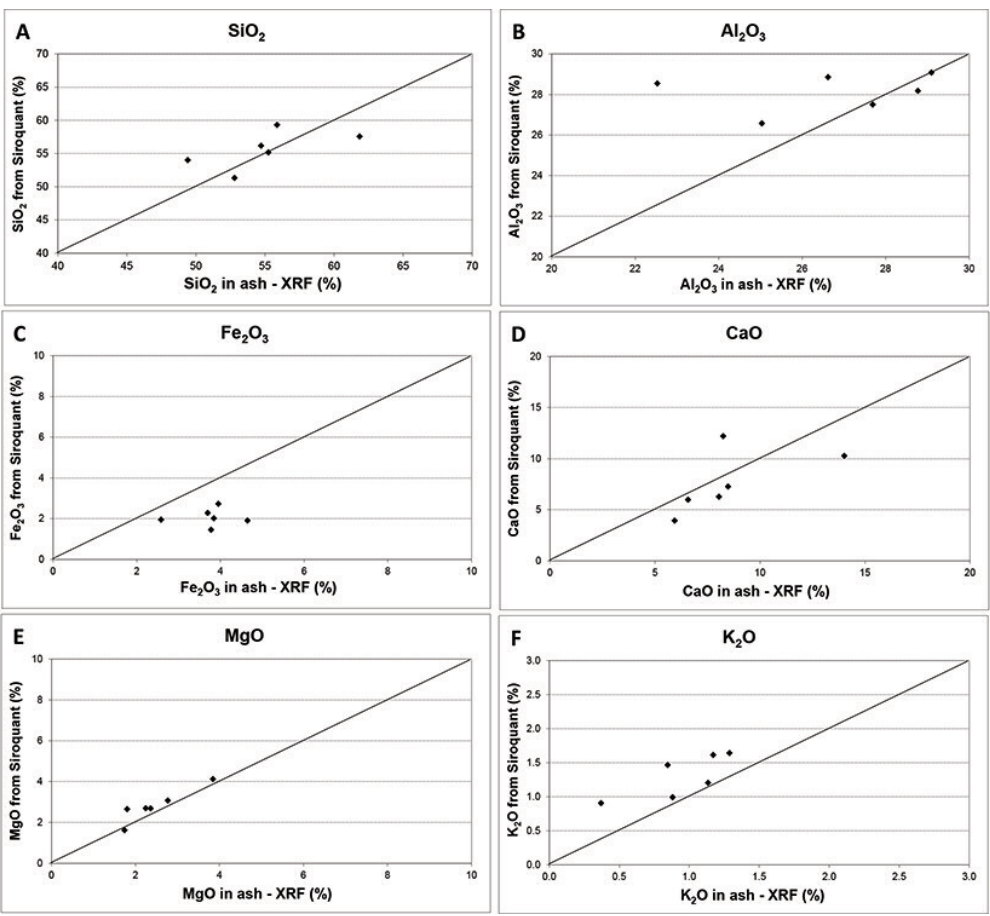

Figure 4-Comparison of major element oxide percentages inferred from quantitative XRD data to observed oxide percentages obtained by direct ash analysis (both normalized to an $\mathrm{SO}_{3}$-free basis). (A) $\mathrm{SiO}_{2}$; (B) $\mathrm{Al}_{2} \mathrm{O}_{3}$; (C) $\mathrm{Fe}_{2} \mathrm{O}_{3}$; (D) $\mathrm{CaO}$; (E) $\mathrm{MgO}$; (F) $\mathrm{K}_{2} \mathrm{O}$. Diagonal line on each plot represents equality 


\section{Determination of mineral matter and elemental composition of individual macerals}

Table IX

Elemental composition of macerals in coal samples by electron microprobe analysis

\begin{tabular}{|c|c|c|c|c|c|c|c|c|c|c|c|c|}
\hline Maceral & Points & $\mathrm{C} \%$ & $\mathrm{~N} \%$ & $0 \%$ & $M g \%$ & $\mathrm{Al} \%$ & Si\% & $\mathrm{S} \%$ & $\mathbf{K} \%$ & $\mathrm{Ca} \%$ & $\mathrm{Ti} \%$ & $\mathrm{Fe} \%$ \\
\hline \multicolumn{13}{|l|}{ Sample 1} \\
\hline $\mathrm{TC}$ & 23 & 73.24 & 2.38 & 18.97 & 0.01 & 0.06 & 0.06 & 0.65 & 0.00 & 0.10 & 0.55 & 0.02 \\
\hline DSC & 12 & 74.82 & 2.46 & 17.39 & 0.01 & 0.10 & 0.11 & 0.67 & 0.01 & 0.10 & 0.44 & 0.00 \\
\hline SF & 15 & 84.40 & 0.98 & 10.21 & 0.01 & 0.02 & 0.04 & 0.30 & 0.01 & 0.07 & 0.02 & 0.00 \\
\hline FUS & 16 & 85.73 & 0.84 & 8.68 & 0.03 & 0.06 & 0.09 & 0.25 & 0.01 & 0.13 & 0.01 & 0.00 \\
\hline \multicolumn{13}{|l|}{ Sample 2} \\
\hline $\mathrm{TC}$ & 23 & 74.34 & 2.29 & 18.00 & 0.03 & 0.10 & 0.07 & 0.79 & 0.01 & 0.13 & 0.38 & 0.00 \\
\hline DSC & 22 & 78.56 & 1.94 & 14.71 & 0.01 & 0.09 & 0.12 & 0.58 & 0.01 & 0.06 & 0.22 & 0.00 \\
\hline SF & 7 & 88.28 & 0.23 & 7.07 & 0.07 & 0.01 & 0.01 & 0.24 & 0.01 & 0.07 & 0.01 & 0.00 \\
\hline FUS & 15 & 89.28 & 0.75 & 6.31 & 0.07 & 0.02 & 0.02 & 0.36 & 0.01 & 0.15 & 0.01 & 0.00 \\
\hline \multicolumn{13}{|l|}{ Sample 3} \\
\hline TC & 15 & 73.17 & 2.41 & 19.83 & 0.01 & 0.41 & 0.33 & 0.76 & 0.05 & 0.06 & 0.38 & 0.00 \\
\hline DSC & 12 & 74.49 & 2.31 & 18.62 & 0.01 & 0.40 & 0.25 & 0.77 & 0.08 & 0.07 & 0.41 & 0.00 \\
\hline SF & 10 & 81.04 & 1.66 & 13.03 & 0.02 & 0.22 & 0.25 & 0.42 & 0.02 & 0.08 & 0.01 & 0.00 \\
\hline FUS & 14 & 83.11 & 1.00 & 11.41 & 0.02 & 0.00 & 0.01 & 0.36 & 0.00 & 0.11 & 0.02 & 0.00 \\
\hline \multicolumn{13}{|l|}{ Sample 4} \\
\hline $\mathrm{TC}$ & 23 & 77.32 & 1.93 & 16.02 & 0.01 & 0.10 & 0.10 & 0.39 & 0.03 & 0.06 & 0.42 & 0.00 \\
\hline DSC & 17 & 77.67 & 2.10 & 15.24 & 0.01 & 0.17 & 0.16 & 0.40 & 0.02 & 0.07 & 0.45 & 0.00 \\
\hline SF & 12 & 85.46 & 0.81 & 9.16 & 0.02 & 0.01 & 0.01 & 0.19 & 0.01 & 0.09 & 0.01 & 0.00 \\
\hline FUS & 14 & 86.36 & 0.99 & 8.43 & 0.04 & 0.01 & 0.02 & 0.18 & 0.01 & 0.17 & 0.01 & 0.00 \\
\hline \multicolumn{13}{|l|}{ Sample 5} \\
\hline TC & 33 & 75.39 & 2.10 & 17.96 & 0.01 & 0.24 & 0.07 & 0.80 & 0.01 & 0.09 & 0.03 & 0.00 \\
\hline DSC & 19 & 76.47 & 2.19 & 16.80 & 0.01 & 0.17 & 0.09 & 0.87 & 0.01 & 0.08 & 0.09 & 0.00 \\
\hline SP & 1 & 79.70 & 1.89 & 15.00 & 0.02 & 0.54 & 0.53 & 1.14 & 0.02 & 0.04 & 0.03 & 0.00 \\
\hline SF & 6 & 86.26 & 0.94 & 9.48 & 0.06 & 0.06 & 0.08 & 0.34 & 0.01 & 0.17 & 0.01 & 0.00 \\
\hline FUS & 8 & 89.22 & 0.43 & 7.39 & 0.04 & 0.09 & 0.07 & 0.37 & 0.01 & 0.12 & 0.00 & 0.00 \\
\hline IDT & 2 & 90.90 & 1.52 & 5.77 & 0.02 & 0.13 & 0.13 & 0.33 & 0.00 & 0.12 & 0.02 & 0.00 \\
\hline \multicolumn{13}{|l|}{ Sample 6} \\
\hline TC & 29 & 69.51 & 2.67 & 23.38 & 0.02 & 0.19 & 0.06 & 0.46 & 0.01 & 0.12 & 0.07 & 0.00 \\
\hline DSC & 21 & 70.06 & 2.55 & 22.06 & 0.02 & 0.20 & 0.08 & 0.47 & 0.01 & 0.17 & 0.06 & 0.00 \\
\hline CUT & 2 & 76.49 & 1.61 & 16.03 & 0.01 & 0.18 & 0.01 & 0.35 & 0.00 & 0.12 & 0.02 & 0.00 \\
\hline SP & 4 & 77.04 & 1.84 & 14.28 & 0.02 & 0.29 & 0.09 & 0.36 & 0.00 & 0.93 & 0.02 & 0.00 \\
\hline SF & 18 & 80.39 & 1.25 & 12.64 & 0.02 & 0.04 & 0.03 & 0.22 & 0.01 & 0.14 & 0.01 & 0.01 \\
\hline FUS & 12 & 85.05 & 0.72 & 9.40 & 0.06 & 0.10 & 0.10 & 0.17 & 0.00 & 0.26 & 0.01 & 0.00 \\
\hline IDT & 5 & 90.13 & 0.68 & 4.23 & 0.02 & 0.02 & 0.01 & 0.20 & 0.00 & 0.43 & 0.01 & 0.00 \\
\hline
\end{tabular}

TC = telocollinite, $\mathrm{DSC}=$ desmocollinite, $\mathrm{SP}=$ sporinite, $\mathrm{CUT}=$ cutinite, $\mathrm{SF}=$ semifusinite, $\mathrm{FUS}=$ fusinite, IDT = inertodetrinite. $\mathrm{Pts}=$ number of points analysed for indicated maceral.

As with other samples studied by this technique (e.g. Ward et al., 2005), the vitrinite macerals in the coals were found to have lower carbon and higher oxygen contents than the inertinite macerals. Collotelinite (referred to in Table IX as telocollinite) generally has a slightly lower carbon content than the collodetrinite (desmocollinite) in the same samples. Comparison with data presented by Ward et al. (2005) indicates that the carbon content of the collotelinite (telocollinite) in most samples (around 75\%) is similar to that of the same maceral in coals from the Bowen Basin of Australia, having a mean maximum vitrinite reflectance of around $0.7 \%$. As indicated in Table IV, similar vitrinite reflectance values are noted for the coal samples analysed in the present study.

The collotelinite (telocollinite) in sample 6, however, has a slightly lower carbon content (around 70\%), yet still has a vitrinite reflectance of $0.7 \%$. The significance of this is not clear at present; it may indicate either a slightly low vitrinite carbon percentage for a coal with a similar rank to the other samples, or a slightly high reflectance for the vitrinite in a coal with a slightly lower rank.

The vitrinite macerals in each individual coal have markedly higher (organic) sulphur and nitrogen contents than the inertinite macerals in the same samples. This is consistent with observations made in other studies (Ward and Gurba, 1998; Mastalerz and Gurba, 2001). In almost all cases the proportions of these elements in the vitrinite macerals are approximately twice those in the same sample's inertinite components.

The proportion of organic sulphur in the vitrinite of samples $1,2,3$, and 5 is around $0.6-0.8 \%$, while the vitrinite of samples 4 and 6 has only $0.4-0.5 \%$ organic sulphur. The significance of this observation is also not clear at present. The absence of any significant iron in these macerals (Table IX) confirms that the sulphur in all cases is organic in nature, and that the higher sulphur levels do not reflect incorporation of submicroscopic pyrite in the macerals concerned.

The overall proportions of carbon, oxygen, and nitrogen for the whole-coal samples, expressed on a dry ash-free basis (Table II) are intermediate between the carbon, oxygen, and nitrogen contents for the vitrinite macerals on the one hand and the inertinite macerals on the other (Table IX), as determined by the electron microprobe study. The total sulphur content of the coals (Table II), however, is significantly higher than the values indicated by microprobe analysis of the mineral-free macerals; this reflects the additional occurrence of pyrite (and thus additional pyritic sulphur) in the mineral-bearing whole-coal samples, as indicated by the mineralogical data in Table V. Macerals containing visible pyrite were avoided in the microprobe 


\section{Determination of mineral matter and elemental composition of individual macerals}

analysis, which was focused on the mineral-free organic components. The proportion of organic sulphur in coals from similar Highveld sources is typically around $0.45 \%$ (Skhonde, 2009), which is between the sulphur concentrations measured by microprobe for the vitrinite and inertinite macerals (Table IX) in most of the coals analysed in the present study.

These comparisons reinforce the well-known but often overlooked fact that coal represents a mixture of different macerals, along with its mineral components. The individual macerals, which may react independently or with each other during utilization, have somewhat different characteristics to the whole-coal chemistry, and thus may follow different reactions at the particle scale to those expected from more conventional whole-coal analysis data.

Despite efforts to avoid including data from points with significant contamination by mineral matter, the vitrinite and semifusinite macerals in sample 3, and possibly also sample 4, appear to contain small, approximately equal, proportions of both $\mathrm{Al}$ and Si. This may suggest incorporation of an intimate admixture of kaolinite or a similar clay mineral into the maceral structure. Lesser, but similarly equal, proportions of $\mathrm{Al}$ and Si are noted in the vitrinite of samples 1 and 2. The vitrinite in samples 5 and 6 appears to have relatively high proportions of Al and only traces of $\mathrm{Si}$, suggesting either the incorporation of bauxite-group minerals (gibbsite and/or boehmite), or possibly incorporation of $\mathrm{Al}$ as an inorganic element within the vitrinite component. The occurrence of $\mathrm{Al}$ in vitrinite, without significant $\mathrm{Si}$, was also noted in microprobe studies by Ward et al. (2007) and Li et al. (2010).

Small proportions (mostly $<0.2 \%$ ) of Ca were noted in the macerals of some coal samples, especially the inertinite macerals. $\mathrm{Ca}$ is especially abundant in the sporinite and inertinite components of sample 6 , probably indicating traces of calcite in the pore spaces of those particular macerals. For the vitrinite macerals, the relatively minor amount of Ca may occur within the organic structure.

The vitrinite in samples 1, 2, 3, and 4 contains significant proportions $(0.3-0.5 \%)$ of titanium. This may occur either as evenly distributed submicroscopic particles ( $c f$. Mares et al., 2012) or be incorporated directly into the maceral structure. Traces of $\mathrm{Ti}(<0.1 \%)$ are also possibly present in the vitrinites of the other two coal samples. Titanium is not, however, present in any of the inertinite components. This provides support for earlier findings by Snyman et al. (1983) that coal float fractions from the Witbank coalfield contain high vitrinite with organically associated titanium, and by van Alphen (2005), who noted the presence of titanium in the vitrinite of South African coals using SEM techniques. The presence of $\mathrm{Ca}, \mathrm{Mg}$, and $\mathrm{Al}$ has also been noted in the macerals of South African coals by van Alphen (2005), based on SEM studies.

More detailed electron microprobe studies using quantitative element mapping (Li et al., 2007) have shown that $\mathrm{Ca}$ and $\mathrm{Al}$ in other coals form an integral part of the maceral structure, rather than representing fine but discrete included mineral particles. Quantitative element mapping using electron microprobe techniques has not, however, been applied to the coals of the present study.

\section{Significance of advanced analytical data}

The typical high ash yield from South African coals, combined with coal mineralogy and ash composition, may be responsible for the formation of clinkers and slags that subsequently erode or block utilization equipment and lower production efficiency during coal combustion and carbon conversion processes (e.g. Matjie et al., 2006; Matjie, 2008; Matjie and van Alphen, 2008). A number of recent studies to evaluate the mineralogical changes that take place in operating gasifiers and packed-bed combustion systems (Matjie et al., 2008, 2011, 2012a, 2012b; Hlatshwayo et al., 2009) have made use of oxygen-plasma ashing and quantitative XRD analysis of different feed coals, combined with chemical and XRD analysis of the associated ash residues and, in some cases, electron microprobe study of individual phases within the ashes and slags. These have shown, inter alia, that the fused material bonding lessreactive, often stony, coal fragments together in clinkers and similar deposits is derived from melting and subsequent cooling of $\mathrm{Ca}$-rich and/or Fe-rich residues left after destruction of low-ash coal particles that originally contained abundant calcite, dolomite, and/or pyrite, and also possibly some non-mineral $\mathrm{Ca}$ or $\mathrm{Fe}$ in the organic components.

Similar studies, linking the mineralogy of ashes from pulverized-fuel power stations to the mineral matter in the respective feed coals, have been published by Ward and French (2006) and Silva et al. (2010). These and other studies (e.g. Creelman et al., 2013) show that the individual components of the mineral matter in the feed coals may react in different ways, with some being essentially non-reactive but others forming phases that may bond to combustion surfaces or interact with other mineral matter products under operating plant conditions.

Data from XRD and geochemical studies may be complemented by information gathered from optical and electron microscopy, including integration of scanning electron microscopy and image analysis techniques (e.g. van Alphen, 2005; French et al., 2008), which indicate the modes of occurrence of the mineral components within the coal or coal products. Indeed, a combination of the two approaches can be used to provide a better understanding of how the mineral matter actually occurs in South African coals, and also how the mode of occurrence impacts on mineral matter behaviour during different utilization processes (e.g. Matjie et al., 2011).

In a different application, Pinetown et al. (2007) used mineralogical data on a range of coals from the Witbank and Highveld coalfields, obtained by oxygen-plasma ashing and quantitative XRD analysis, to evaluate the balance between phases that may give rise to acid leachates (e.g. pyrite) and phases such as calcite and dolomite, which have the potential to neutralize those acids in field situations. Acid-base accounting data generated from such studies was noted as being of value in making plausible predictions concerning the potential of the coal and non-coal rocks to contribute to acid mine drainage in these and other coalfield areas.

The mineral matter in the feed coals may be responsible for volatilization of minor amounts of $\mathrm{Al}$ and $\mathrm{Si}$ during combustion and carbon conversion processes (Matjie et al., 2006; Matjie and van Alphen, 2008). In addition, some of the expandable-lattice clay minerals in the coal samples may 


\section{Determination of mineral matter and elemental composition of individual macerals}

react at elevated temperatures to form ultrafine ash particles containing aluminosilicate species (Matjie, 2008; van Alphen, 2005). The aluminosilicate species from these ultrafine ash particles may then dissolve in the plant water and form a colloidal aluminium silicate precipitate, which builds up on the heat exchanger plates during the liquid-liquid extraction process (Matiie and Engelbrecht, 2007). Formation of this gelatinous precipitate is an operational problem that may result in a severe blockage of the heat exchanger plates and eventually need to be removed with hydrofluoric acid, a toxic and corrosive chemical. The potential for such issues may therefore need to be taken into account by incorporating mineralogical data into the blending of coal feedstocks for industrial use.

The non-mineral inorganic elements (e.g. $\mathrm{Ca}, \mathrm{Mg}$ ) in lignitic coals have been shown to react with aluminium silicates released from breakdown of other minerals to form fused agglomerates during the combustion process (e.g. Quann and Sarofim, 1986). They may also be responsible for evolution of corrosive and polluting gases such as hydrogen sulphide, carbonyl sulphide, and sulphur oxides (Ozum et al., 1993), and the formation of ultrafine ash particles, as well as condensed metallic vapours, during coal combustion and carbon conversion processes (Zhang et al, , 2006; Buhre et al., 2006; Matjie, 2008). Recognition of such elements, through either electron microprobe analysis or more conventional studies, may help to minimize the potential for corrosion, slagging, and fouling in operating combustion and gasification plants (Creelman et al., 2013), as well as the emission of gases and/or fine particulates with potential for adverse environmental impacts.

\section{Conclusions}

A number of advanced analytical techniques, including lowtemperature oxygen-plasma ashing, quantitative X-ray diffraction analysis, and light-element electron microprobe analysis, have been combined with more conventional methods (proximate and ultimate analysis, ash analysis, and petrographic studies) to evaluate the mineral and organic matter in coals from several Highveld mines, used as feedstock for combustion and carbon conversion processes. Such a combination of techniques allows better evaluation of the proportions of fluxing minerals (pyrite, dolomite, and calcite) and organically-bound inorganic elements that appear to be responsible for clinker and slag formation, as well as the volatilization of inorganic elements and sulphur emissions associated with these and other activities.

The proportions of mineral matter in the coals studied, as indicated by low-temperature oxygen-plasma ashing, are higher than the proportions of ash indicated by conventional proximate analysis, reflecting the decomposition of clays, carbonates, and other minerals in the coals at the high temperatures used in the proximate analysis process. If allowance is made for the higher density of the minerals relative to the macerals, this is also consistent with the volumetric percentages of mineral components determined by optical microscopy and petrographic analysis.

Kaolinite is the most abundant of the minerals in the coal samples, with lesser but still significant proportions of quartz, mica and/or illite, dolomite, calcite, and pyrite. Small but variable proportions of anatase, goyazite, and siderite are present in some samples. Bassanite, which also occurs in the LTA residues, was probably formed by interaction of nonmineral $\mathrm{Ca}$ with $\mathrm{S}$ released from the organic matter during the plasma-ashing process. More detailed XRD analysis of the clay $(<2 \mu \mathrm{m})$ fractions of the LTA samples, using ethylene glycol and heat treatment, has further identified the nature of the expandable clay minerals (smectite and interstratified illite/smectite) present in the coal samples.

Light-element electron microprobe techniques have enabled direct measurement of the carbon, oxygen, nitrogen, and organic sulphur contents of the individual macerals in the coals, providing determinations that are possible in conventional analysis only by indirect techniques (e.g. oxygen, organic sulphur). The vitrinite was found to contain less carbon and more oxygen, and to have significantly higher concentrations of nitrogen and organic sulphur, than the inertinite macerals in the same coal samples. Minor proportions of organically-associated inorganic elements, including $\mathrm{Ca}, \mathrm{Al}, \mathrm{Si}, \mathrm{Mg}$, and $\mathrm{Ti}$, were also identified in the macerals, especially (for Ti) in the vitrinite components.

As well as the crystalline mineral phases, non-mineral inorganic elements such as $\mathrm{Ca}$ and $\mathrm{Mg}$ may contribute to, and even promote, the formation of clinkers and slags in plant equipment at the elevated temperatures associated with coal combustion and carbon conversion processes. Along with pyrite and organic sulphur in the coals, they may also be responsible for the evolution of corrosive gases (hydrogen sulphide and sulphur oxides), formation of ultrafine ash particles, fouling of water by aluminium silicate, and generation of condensed metallic vapours during the coal combustion and carbon conversion processes.

A comprehensive knowledge of the minerals and nonmineral inorganic elements in the coals used for feedstock preparation, gathered by integration of conventional and more advanced analytical techniques, may be of benefit in understanding the processes that take place during coal utilization, and in avoiding or ameliorating some of the operational and environmental problems that may occur in different sectors of the coal utilization industry.

\section{Acknowledgements}

This paper was developed from a collaborative research programme between Sasol Technology Research and Development, the University of New South Wales, and NorthWest University. The assistance provided by Sarel du Plessis, Elias Nana, and the Highveld Coalfield Group is also acknowledged. The authors would like to thank the management of Setpoint Laboratories in Johannesburg and Coal and Mineral Technologies (Pty) Ltd for providing the analytical facilities for basic characterization of the coals. Barry Searle and Irene Wainwright of the University of New South Wales, and Harold Read and Walter Pickel of Coal and Organic Petrology Services, are thanked for assistance with different aspects of the analytical programme. The work was also based on research supported by the South African Research Chairs Initiative of the Department of Science and Technology and National Research Foundation of South Africa (Coal Research Chair Grant No. 86880, UID85643, UID85632). Any opinion, finding, or conclusion or recommendation expressed in this material is that of the authors and the NRF does not accept any liability in this regard. 


\section{Determination of mineral matter and elemental composition of individual macerals}

\section{References}

BARnES, I. 2009. Slagging and Fouling in Coal-Fired Boilers. IEA Clean Coal Centre, London, U.K., Report CCC/147, 43 pp.

Benson, S.A. 1987. Laboratory studies of ash deposit formation during the combustion of Western U.S. coals. PhD thesis, Pennsylvania State University.

BRYERS, R.W. 1996. Fireside slagging, fouling, and high-temperature corrosion of heat transfer surfaces due to impurities in steam raising fuels. Progress in Energy and Combustion Sciences, vol. 22. pp. 29-120

Buhre, B.J.P., Hinkley, J.T., Gupta, R.P., Nelson, P.F., and Wall, T.F. 2006. Fine ash formation during combustion of pulverised coal: coal property impacts. Fuel, vol. 85. pp. 185-193.

Bustin, R.M., MASTALERZ, M., and WilKs, K.R. 1993. Direct determination of carbon, oxygen and nitrogen content in coal using the electron microprobe. Fuel, vol. 72. pp. 181-185.

Clark, C.P., Freeman, G.B., and Hower, J.C. 1984. Non-matrix corrected organic sulphur determination by energy dispersive X-ray spectroscopy for western Kentucky coals and residues. Scanning Electron Microscopy, vol. 2 , pp. $537-545$.

Creelman, R.A., Ward, C.R., Schumacher, G., and JuniPer, L. 2013. Relation between coal mineral matter and deposit mineralogy in pulverized fuel furnaces. Energy \& Fuels, vol. 27. pp. 5714-5724.

Department Of Minerals And Energy (DME), South Africa. 2006. Operating and developing coal mines in the Republic of South Africa. Directory D2/2006.

Falcone, S.K., Schobert, H.H., Rindt, D.K., and Braun, S. 1984. Mineral transformations during ashing and slagging of selected low-rank coals. Fuel Chemistry, vol. 29, no. 4. pp. 76-82.

Frazer, F.W., and BeLCHER, C.B. 1973. Quantitative determination of the mineral-matter content of coal by a radiofrequency-oxidation technique. Fuel, vol. 52, pp. 41-46.

FRENCH, D. WARD, C.R.., and BUTCHER, A. 2008. QEMSCAN for characterisation of coal and coal utilisation by-products, Research Report 93. Co-operative Research Centre for Coal in Sustainable Development, Brisbane, Australia. 103 pp.

GAIGHER, G.L. 1980. Mineral matter in some South African coals. MSc thesis University of Pretoria.

GLUSKOTER, H.J. 1965. Electronic low temperature ashing of bituminous coal. Fuel, vol. 44. pp. 285-291.

GRIFFIN, G.M. 1971. Interpretation of X-ray diffraction data. Procedures in Sedimentary Petrology. Carver, R.E. (ed.). Wiley-Interscience, New York.

Grigore, M., SAKurovs, R., French, D., and SAhajwalla, V. 2008. Mineral matter in coals and their reactions during coking. International Journal of Coal Geology, vol 76. pp. 301-308.

Gupta, S.K., Wall, T.F., Creelman, R.A., and Gupta, R. 1996. Ash fusion temperatures and the transformations of coal ash particles to slag. Proceedings of the ACS Division of Fuel Chemistry Spring National Meeting, Symposium on Ash Chemistry: Phase Relationships in Ashes and Slags, New Orleans, LA, 24-28 March. pp. 647-651.

HARDY, R.G. and Tucker, M.E. 1988. X-ray powder diffraction of sediments.
Techniques in Sedimentology. Tucker, M.E. (ed.). Blackwell Scientific., Oxford, UK., pp. 191-228.

Hlatshwayo, T.B., MatjIE, R.H., LI, Z., and Ward, C.R. 2009. Mineralogical characterization of Sasol feed coals and corresponding gasification ash constituents. Energy \& Fuels, vol. 23. pp. 2867-2873.

InTERnATIONAL StANDARDS AsSOciation (ISO). 2005. Classification of coals. ISO11760-2005. Geneva. 9 pp

KoukouZAS, N., WARD, C.R., PAPANiKolAou, D., and Li, Z. 2009. Quantitative evaluation of minerals in lignites and intra-seam sediments from the Achlada Basin, northern Greece. Energy \& Fuels, vol. 23. pp. 2169-2175.

LI, Z., WARD, C.R., and GuRBA, L.W. 2007. Occurrence of non-mineral inorganic elements in low-rank coal macerals as shown by electron microprobe element mapping techniques. International Journal of Coal Geology, vol. 70. pp. 137-149.

LI, Z., WARD, C.R., and GURBA, L.W. 2010. Occurrence of non-mineral inorganic elements in macerals of low-rank coals. International Journal of Coal Geology, vol. 81. pp. 242-250.

Mares, T.E., Radlinski, A.P., Moore, T.A., Cookson, D., Thiyagarajan, P., ILAVSKY, J., and KLEPP, J. 2012. Location and distribution of inorganic material in a low ash yield, subbituminous coal. International Journal of Coal Geology, vol. 94, pp. 173-181.

MASTALERZ, M. and GURBA, L.W. 2001. Determination of nitrogen in coal macerals using electron microprobe technique - experimental procedure. International Journal of Coal Geology, vol. 47. pp. 23-30.

MATJE, R.H. 2008. Sintering and slagging of mineral matter in South African coals during the coal gasification process. PhD thesis, University of Pretoria, Pretoria, South Africa.

MATJIE, R.H. and ENGELBRECHT, R. 2007. Selective removal of dissolved silicon and aluminium ions from gas liquor by hydrometallurgical methods. Hydrometallurgy, vol. 85. pp. 172-182.

MAtjie, R.H., Li, Z., WARd, C.R., and French, D. 2008. Chemical composition of glass and crystalline phases in coarse coal gasification ash. Fuel, vol. 87, pp. 857-869.

Matjie, R.H., French, D., Ward, C.R., Pistorius, P.C., and Li, Z. 2011. Behaviour of coal mineral matter in sintering and slagging of ash during the gasification process. Fuel Processing Technology, vol. 92. pp. 1426-1433.

MATJIE, R.H., WARD, C.R., and LI, Z. 2012a. Mineralogical transformations in coal feedstocks during carbon conversion, based on packed bed combustor tests. Part 1: Bulk coal ash studies. Coal Combustion and Gasification Products, vol. 4. pp. 45-54.

MATJIE, R.H., WARD, C.R., and LI, Z. 2012b. Mineralogical transformations in coal feedstocks during carbon conversion, based on packed bed combustor tests. Part 2: Behaviour of individual particles. Coal Combustion and Gasification Products, vol. 4. pp. 55-67.

MATjiE, R.H., and VAn Alphen, C. 2008. Mineralogical features of size and density fractions in Sasol coal gasification ash, South Africa and potential by-products. Fuel, vol. 87. pp. 1439-1445.

MAtje, R.H., VAn Alphen, C., and Pistorius, P.C. 2006. Mineralogical characterisation of Secunda gasifier feedstock and coarse ash. Minerals Engineering, vol. 19, no. 3. pp. 256-261. 


\section{Determination of mineral matter and elemental composition of individual macerals}

NoRRISH, K. and HutTon, J.T. 1969. An accurate X-ray spectrographic method for the analysis of a wide range of geological samples. Geochimica et Cosmochimica Acta, vol. 33. pp. 431-453.

O'GORMAN, J.V. and WALKER, P.L. 1973. Thermal behaviour of mineral fractions separated from selected American coals. Fuel, vol. 52. pp. 71-79.

Ozum, B., Коvacik, G., and Chambers, A. 1993. Coal gasification gas clean-up; International Journal of Hydrogen Energy, vol. 18, no. 10. pp. 847-851.

Pinheiro, H.J., Pretorius, C.C., and Boshoff, H.P. 1998-1999. Analyses of coal product samples of South African collieries. Part 2, DME, SABS and CSIR Bulletin, no. 113. pp. 64-93.

Pinetown, K.L., Ward, C.R., and Van Der Westhuizen, W.A. 2007. Quantitative evaluation of minerals in coal deposits in the Witbank and Highveld Coalfields and the potential impact on acid mine drainage. International Journal of Coal Geology, vol. 70. pp, 166-183.

QuanN, R.J. and SARofim, A.F. 1986. A scanning electron microscopy study of the transformations of organically-bound metals during lignite combustion. Fuel, vol. 65. pp. 40-46.

RAYmond JR., R. and Gooley, R. 1978. A review of organic sulphur in coal and a new procedure. Scanning Electron Microscopy, vol. 1. pp. 93-107.

RAYMOND JR., R. 1982. Electron probe microanalysis: a means of direct determination of organic sulphur in coal. Coal and Coal Products: Analytical Characterization Techniques. Fuller Jr., E.L. (ed.). American Chemical Society Symposium Series, vol. 205. pp. 191-203.

RieTveLD, H.M. 1969. A profile refinement method for nuclear and magnetic structures. Journal of Applied Crystallography, vol. 2. pp. 65-71.

RyAn, B.D. and LEDDA, A. 1997. A review of sulphur in coal: with specific reference to Tewa deposit. North-Western British Columbia, in geological fieldwork, B.C. Ministry of Employment and Investment, paper 1998-1. pp. 29-1 to $29-21$

Silva, L.F.O., WARd, C.R., Hower, J.C., IZQuierdo, M., WAANDERS, F., OliveirA, M.L.S., LI, Z., HATch, R.S., and Querol, X. 2010. Mineralogy and leaching characteristics of coal ash from a major Brazilian power plant. Coal Combustion and Gasification Products, vol. 2. pp. 51-65.

SKHoNDE, M.P. 2009. Sulphur behaviour and capturing during a fixed-bed gasification process of coal. PhD thesis, School of Physical and Chemical Sciences, North-West University, Potchefstroom, South Africa.

Snyman, C.P., VAn Vuuren, M.C.J., and Barnard, J.M. 1983. Chemical and physical characteristics of South African coal and a suggested classification system. National Institute for Coal Research, Coal 8306. pp. 1-63.

Standards Australia. 2000. Higher rank coal - mineral matter and water of constitution. Australian Standard 1038 Part 22. Standards Australia, Sydney, 20 pp.

Su, S., Pohl, J.H., HolcomBe, D., and HART, J.A. 2001. Slagging propensities of blended coals. Fuel, vol. 80. pp. 1351-1360

TANGSATHITKUlChaI, M. 1986. Studies of the initiation, growth and sintering in the formation of utility boiler deposits. PhD thesis, Pennsylvania State University, University Park, PA.
TAYLOR, J.C. 1991. Computer programs for standardless quantitative analysis of minerals using the full powder diffraction profile. Powder Diffraction, vol. 6. pp. 2-9.

VAn AlPhen, C. 2005. Factors influencing fly ash formation and slag deposit formation (slagging) on combusting a South African pulverized fuel in a 200 Me boiler. PhD thesis, Faculty of Engineering and the Built Environment, University of the Witwatersrand, Johannesburg.

Van Dyk, J.C., Keyser, M.J., and Coertzen, M. 2006. Syngas production from South African coal sources using Sasol-Lurgi gasifiers, International Journal of Coal Geology, vol. 65. pp. 243-253.

VAssilev, S.V., KitANo, K., TAKEDA, S., and TsuruRE, T. 1995. Influence of mineral and chemical composition of coal ashes on their fusibility. Fuel Processing Technology, vol. 45. pp. 27-51.

Wall, T., Elliott, L., Zhang, D.K., French, D., Creelman, R., Gupta, S., and Vuthaluru, H.B. 2002. Relating Coal Properties to Ash Deposition and Slagging: Tools for Investigation of Deposit Samples. Report C10060. Australian Coal Association Research Program (ACARP), Brisbane, Queensland, Australia.

WARD, C.R. 2002. Analysis and significance of mineral matter in coal seams. International Journal of Coal Geology, vol. 50. pp. 135-168.

WARD, C.R. and FRENCH, D. 2006. Determination of glass content and estimation of glass composition in fly ash using quantitative X-ray diffractometry. Fuel, vol. 85. pp. 2268-2277.

WARD, C.R. and GURBA, L.W. 1998. Occurrence and distribution of organic sulphur in macerals of Australian coals using electron microprobe techniques. Organic Geochemistry, vol. 28, no. 11. pp. 635-647.

WARD, C.R., LI, Z., and GuRBA, L.W. 2005. Variations in coal maceral chemistry with rank advance in the German Creek and Moranbah Coal Measures of the Bowen Basin Australia using electron microprobe techniques. International Journal of Coal Geology, vol. 63. pp. 117-129.

WARD, C.R., LI., Z., and GURBA, L.W. 2007. Variations in elemental composition of macerals with vitrinite reflectance and organic sulphur in the Greta Coal Measures, New South Wales, Australia. International Journal of Coal Geology, vol. 69. pp. 205-219.

WARD, C.R., LI, Z., and GuRBA, L.W. 2008. Comparison of elemental composition of macerals determined by electron microprobe to whole-coal ultimate analysis data. International Journal of Coal Geology, vol. 75. pp. $157-165$.

Ward, C.R., Matulis, C.E., TAYLoR, J.C., and Dale, L.S. 2001. Quantification of mineral matter in the Argonne Premium Coals using interactive Rietveldbased X-ray diffraction. International Journal of Coal Geology, vol. 46. pp. 67-82.

Ward, C.R., Spears, D.A., Booth, C.A., Staton, I., and Gurba. L.W. 1999. Mineral matter and trace elements in coals of the Gunnedah Basin, New South Wales, Australia. International Journal of Coal Geology, vol. 40. pp. 281-308.

Zhang, L., NinomiYa, Y., and Yamashita, T. 2006. Occurrence of inorganic elements in condensed volatile matter emitted from coal pyrolysis and their contributions to the formation of ultra-fine particulates during coal combustion. Energy \& Fuels, vol. 20. pp. 1482-1489. 